\title{
Mainstreaming Ecosystem Services Based Climate Change Adaptation (EbA) in Bangladesh: Status, Challenges and Opportunities
}

\author{
Nazmul Huq ${ }^{1,2, *}$, Antje Bruns ${ }^{2}$, Lars Ribbe ${ }^{1}$ and Saleemul Huq ${ }^{3}$ \\ 1 ITT-Institute for Technology and Resources Management in the Tropics and Subtropics, \\ TH Köln (University of Applied Sciences), Betzdorfer Straße 2, 50679 Köln (Deutz), Germany; \\ lars.ribbe@fh-koeln.de \\ 2 Governance and Sustainability Lab, Department VI-Spatial and Environmental Sciences, \\ University of Trier, 54286 Trier, Germany; brunsa@uni-trier.de \\ 3 International Centre for Climate Change Adaptation and Development (ICCCAD), Independent University, \\ Bangladesh, Plot 16 Block B, Aftabuddin Ahmed Road, Bashundhara R/ A, 1220 Dhaka, Bangladesh; \\ saleemul.huq@iied.org \\ * Correspondence: nazmulhuqrussell@gmail.com or nahuq@th-koeln.de
}

Academic Editor: Yu-Pin Lin

Received: 28 March 2017; Accepted: 24 May 2017; Published: 1 June 2017

\begin{abstract}
The paper aims to analyze the extent of Ecosystem Service (ESS) based Adaptation (EbA) to climate change in the policy-making process of Bangladesh. The paper is based on a three stage hybrid policy-making cycle: (i) agenda setting; (ii) policy formulation; and (iii) policy implementation stage, where the contributions of EbA can horizontally (on the ground) or vertically (strategic stage) be mainstreamed and integrated. A total of nine national and sectoral development and climate change policies, and 329 climate change adaptation projects are examined belonging to different policy-making stages. The major findings include that the role of ESS is marginally considered as an adaptation component in most of the reviewed policies, especially at the top strategic level (vertical mainstreaming). However, at the policy formulation and implementation stage (horizontal mainstreaming), they are largely ignored and priority is given to structural adaptation policies and projects, e.g., large scale concrete dams and embankments. For example, ESS's roles to adapt sectors such as urban planning, biodiversity management and disaster risk reduction are left unchecked, and the implementation stage receives overwhelming priorities and investments to undertake hard adaptation measures such that only 38 projects are related to EbA. The paper argues that: (i) dominant structural adaptation ideologies; (ii) the expert and bureaucracy dependent policy making process; and (iii) the lack of adaptive and integration capacities at institutional level are considerably offsetting the EbA mainstreaming process that need to be adequately addressed for climate change adaptation.
\end{abstract}

Keywords: Bangladesh; climate change adaptation; Ecosystem services based Adaptation (EbA); ecosystem services; mainstreaming

\section{Introduction}

Ecosystem services (ESS) can be defined as the benefits that humans obtain from ecosystems such as food, water, climate regulation, etc. in form of provisioning, regulating, supporting and cultural services [1-4]. The role of ESS to enhance the adaptation capacities to climate change impacts is increasingly evident and important in the scientific literature [5], international environmental policies [6] and often at national policy level [7]. ESS based adaptation approaches (EbA) have proven to be one of the most effective and sustainable adaptation techniques against climatic disasters and impacts. Examples include, coastal disasters and cyclones through coastal forestry and wetland [8,9], 
drought management through plantation and soil management [10], sustainable water management through water purification and flow regulation [11], urban disaster management through greening and Sustainable Urban Drainage (SUD) [4], flood management through floodplain extension and allowing space for rivers [7,12], and enhancing human livelihood provisions and security through better ecosystem management and resource efficiency [13-15], to name a few. EbA approach can broadly be defined as the sustainable use of ESS in a comprehensive adaptation strategy to strengthen societal resilience against the adverse impacts of climate change $[6,10,13]$.

EbA approach is a combination of both "soft" and "hard" approaches of adaptation designed to harness the capacity of ecosystem and nature [16]. "Soft" approaches of adaptation include information, policies, capacity building and institutional governance, whereas the "hard approach" requires technology and capital intensive infrastructural based interventions such as sea walls and dykes [16,17]. EbA's capacities to provide multiple benefits to society and ecosystems such as reducing disaster and climate risks through natural infrastructure, supplying livelihood capitals, maintaining ecosystem's balance, etc. can simultaneously occur in a cost-effective way without any major trade-offs [18]. In additional, there are numerous non-marketable social, environmental and economic (co-)benefits of EbA which are pivotal forces of local development through strengthening local adaptive capacities $[19,20]$. Table 1 provides examples of the EbA approaches in different areas and sectors, measures, adaptation services and financial appraisals to hard adaptation methods. The lists in Table 1 regarding sectors, measures and benefits are no way exhaustive, however, highlight the major intervention areas where EbA can be instrumental to promote adaptation namely agriculture and food security, forestry, biodiversity, DRR, urban planning, coastal and water resource management $[11,21,22]$.

$\mathrm{EbA}$, thus, offers a set of flexible, regretless and cost effective adaptation intervention to avoid uncertain capital investment as well as to promote soft adaptation methods $[16,23]$. Incorporation of $\mathrm{EbA}$ in development and climate policies, therefore, promotes sustainable adaptation and development for communities, decision makers and ecosystems as well as pave an "in-built" pathway to achieve Sustainable Development Goals (SDG) [24]. Moreover, $60 \%$ of global supplies of ecosystem services are already being degraded or subject of unsustainable management [25].

Given that backgrounds and in the persuasion of an integrated adaptation and development approach, EbA has the capacity to play an important role for achieving SDGs involving ecosystem management, CCA, and disaster risk reduction (DRR) than the single-disciplinary approach of adaptation, development, and ecosystem management $[10,18,26]$. In addition, in many instances, EbA represents the only feasible adaptation options to implement, for example, coastal fishing communities in small island states [16]. Therefore, EbA deservedly needs better attention at political agenda setting level, and needs mainstreaming at the climate and development policy and practice levels. Mainstreaming EbA at policy level enhances systematic integration of adaptation into ecosystem management and development activities and to ensure necessary financial, human, technological and knowledge supports [17,27-31].

In reality, EbA approaches and methods are still in their infancies [32]. National governments, international organizations and non-governmental organizations have initiated the integration of $\mathrm{EbA}$ into policy and management but it has not yet been established as a standard practice $[7,33]$. In theory, EbA can be "embedded into national, regional and local policy and practice by adopting an integrated, participatory and ecosystem-based approach to territorial planning" [3] for integrated development and adaptation. In recent years, the number of pilot EbA projects and scientific studies are steadily increasing; however, that does not guarantee an automatic inclusion into the policy and practice [34]. In order to unlock the potentials of $\mathrm{EbA}$, one of the key cornerstones is to make interventions at the policy making and planning areas across scales $[18,35]$. It is also fundamentally essential that current extent of EbA inclusion in the development and adaptation process is necessary assessed. Once the extent is identified, potential scopes, entry points, strengths, weaknesses and challenges can be underlined and addressed. 
Table 1. Application of ESS based adaptation, potentials areas of interventions, measures, benefits and economic appraisals.

\begin{tabular}{|c|c|c|c|c|}
\hline \multirow{2}{*}{ Areas of Intervention } & \multirow{2}{*}{ Examples Relevant ESS Measures } & \multirow{2}{*}{ Examples of Contributions to Adaptation } & \multicolumn{2}{|c|}{ Examples of Economic Implications } \\
\hline & & & ESS Based Adaptation & Conventional (e.g., Hard) Adaptation \\
\hline $\begin{array}{l}\text { Agriculture and } \\
\text { food security }\end{array}$ & $\begin{array}{l}\text { - Soil moisture conservation practices, } \\
\text { - } \quad \text { Rain fed wanic fertilizer } \\
\text { harvesting techniques } \\
\text { - Application of low tillage } \\
\text { cultivation, crop rotation, } \\
\text { agro-forestry, promoting local and } \\
\text { climate tolerant varieties }\end{array}$ & $\begin{array}{l}\text { - } \quad \text { Increased production and income } \\
\text { - } \quad \text { Protection of water sources and better } \\
\text { ground water regulation } \\
\text { Diversification improves crop } \\
\text { sustainability against extreme } \\
\text { weather, pest and weed }\end{array}$ & $\begin{array}{l}\text { - Malawi farmers increased average yields } \\
\text { fourfold at minimal cost, using } \\
\text { intercropping, different sowing date and } \\
\text { improved varieties }\end{array}$ & $\begin{array}{l}\text { - To increase average yields } \\
\text { fourfold by using inorganic } \\
\text { fertilizers would cost Malawi } \\
\text { farmers US } \$ 11.6 \mathrm{~m} / \text { year }\end{array}$ \\
\hline $\begin{array}{l}\text { Disaster Risk Reduction } \\
\text { (DRR) }\end{array}$ & $\begin{array}{l}\text { - Maintenance and restoration of } \\
\text { mangrove and other forests } \\
\text { - } \quad \text { River and floodplain restoration } \\
\text { and providing space for water } \\
\text { - } \quad \text { Dune restoration, sand nourishment }\end{array}$ & $\begin{array}{l}\text { Ensures coastal protection through } \\
\text { minimizing cyclonic wind, tidal } \\
\text { surges and coastal erosion } \\
\text { - Reduce flood damage through more } \\
\text { water accommodation in the river }\end{array}$ & $\begin{array}{l}\text { - Coral reefs are natural barrier that } \\
\text { provide protection against erosion and } \\
\text { wave damage. In the Turks and Caicos } \\
\text { Islands this protection is valued at } \\
\text { US } \$ 16.9 \mathrm{~m} / \text { year }\end{array}$ & $\begin{array}{l}\text { - The cost of hard engineering } \\
\text { options (dykes and levees) for } \\
\text { coastal protection in the Turks and } \\
\text { Caicos Islands has been estimated } \\
\text { US } \$ 223 \text { million }\end{array}$ \\
\hline Forestry & $\begin{array}{l}\text { - Increasing, creating and replanting } \\
\text { existing natural forests and coastal } \\
\text { green belts } \\
\text { - Promoting agro-forestry system } \\
\text { according to ecosystem types } \\
\text { - } \quad \begin{array}{l}\text { Promoting participatory and } \\
\text { community forestry }\end{array} \\
\text { - Protection of watershed forests }\end{array}$ & $\begin{array}{l}\text { - Minimize flood risk through } \\
\text { attenuation of water coming } \\
\text { from upstream } \\
\text { - Significantly reduce and control heat } \\
\text { and helps to grow better crops } \\
\text { - Improved soil moister through water } \\
\text { retention, reduce production costs } \\
\text { and increase income } \\
\text { - Increase sedimentation and improve } \\
\text { water quality }\end{array}$ & $\begin{array}{l}\text { - Since 1994, in Vietnam an initial } \\
\text { investment of US\$1.1 million for creating } \\
\text { mangrove significantly reduced typhoon } \\
\text { risks, protected lives and properties than } \\
\text { other areas with dyke protection } \\
\text { Sustainable forestry in Cameroon ( low } \\
\text { impacts logging with small scale farming) } \\
\text { yielded worth of } \$ 2570 / \text { ha plus } \\
\text { associated benefits of sedimentation and } \\
\text { flood control [6] }\end{array}$ & $\begin{array}{l}\text { An estimated US } \$ 7.3 \text { million a } \\
\text { year is necessary for sea dyke } \\
\text { maintenance; and lives and } \\
\text { property losses were higher } \\
\text { Plantation such as palm and } \\
\text { rubber produced } 18 \text { percent less } \\
\text { total economic value (TEV) than } \\
\text { sustainable forestry [6] }\end{array}$ \\
\hline
\end{tabular}


Table 1. Cont

\begin{tabular}{|c|c|c|c|c|}
\hline \multirow{2}{*}{ Areas of Intervention } & \multirow{2}{*}{ Examples Relevant ESS Measures } & \multirow{2}{*}{ Examples of Contributions to Adaptation } & \multicolumn{2}{|c|}{ Examples of Economic Implications } \\
\hline & & & ESS Based Adaptation & Conventional (e.g., Hard) Adaptation \\
\hline Water management & $\begin{array}{ll}\text { - } & \text { River, canals and floodplain } \\
\text { renaturation/restoration } \\
\text { - } \\
\text { Habitat restoration, creation } \\
\text { and protection } \\
\text { - Watershed and wetland } \\
\text { management, dyke relocation } \\
\text { - Rain fed water } \\
\text { harvesting techniques }\end{array}$ & $\begin{array}{l}\text { - Minimize flood and other disaster } \\
\text { risks such as urban waterlogging } \\
\text { - Conserve and increase biodiversity } \\
\text { and genetic diversities } \\
\text { - Heat and erosion control, } \\
\text { improved fisheries } \\
\text { - Better irrigation system and less } \\
\text { dependence of groundwater } \\
\text { - Improved agricultural productivity }\end{array}$ & $\begin{array}{l}\text { The Paramo wetland ecosystem above } \\
\text { Bogota, Colombia filters out water } \\
\text { contaminants and sediments which saves } \\
\text { US } \$ 19.6 \mathrm{~m} / \text { year to the city } \\
37 \text { floodplain sites restoration in the } \\
\text { Danube region costs } \$ 299 \text { million, but } \\
\text { provide income of } \$ 120 \mathrm{~m} / \text { year in } \\
\text { addition to reduced flood risk, improved } \\
\text { water supply, fisheries, biodiversity, } \\
\text { agriculture and tourism }\end{array}$ & $\begin{array}{l}\text { - The cost of building water } \\
\text { reservoir to store water until } 2032 \\
\text { is for three municipalities in } \\
\text { Colombia estimated at } \\
\text { US } \$ 127 \text { million } \\
\text { Before restoration, } 2005 \text { Danube } \\
\text { alone cost } \$ 435 \text { million } \\
\text { in damages }\end{array}$ \\
\hline Urban adaptation & $\begin{array}{l}\text { - Increasing use of green and blue } \\
\text { infrastructure, e.g., green belts, } \\
\text { roofs, lakes and waterbodies } \\
\text { Implement sustainable urban } \\
\text { drainage (SUD) technology }\end{array}$ & $\begin{array}{l}\text { Reduce heat island effect, improve air } \\
\text { and water quality and overall urban } \\
\text { living environment } \\
\text { Control urban flooding and provide } \\
\text { improved urban } \\
\text { drainage management }\end{array}$ & $\begin{array}{l}\text { About } 9 \text { million New York city residents } \\
\text { receives } 90 \% \text { of their water from the } \\
\text { Catskill-Delaware watershed which } \\
\text { protection costs US } \$ 150 \mathrm{~m} / \text { year to } \\
\text { the city }\end{array}$ & $\begin{array}{l}\text { - The cost of a water filtration plant } \\
\text { sufficient to filter water for New } \\
\text { York would have cost US\$6b-8b } \\
\text { up front plus US } \$ 300 \mathrm{~m} / \text { year } \\
\text { operating costs }\end{array}$ \\
\hline Biodiversity & $\begin{array}{l}\text { - Providing ecological corridors } \\
\text { Protection of key species, } \\
\text { maintaining genetic diversity, } \\
\text { removal of alien species } \\
\text { Application of low tillage } \\
\text { cultivation, crop rotation, } \\
\text { agro-forestry, promoting } \\
\text { local varieties }\end{array}$ & $\begin{array}{l}\text { - Improve ecosystem's health and } \\
\text { thereby better ecosystem services } \\
\text { - Increase tourism and local } \\
\text { economic benefits } \\
\text { - Maintains soil fertility, soil moisture } \\
\text { and ground water resources }\end{array}$ & $\begin{array}{l}\text { - In Sweden, ESS based agricultural } \\
\text { practices, e.g., intercropping, crop } \\
\text { rotations, and multiple sowing dates, } \\
\text { provide agro-diversity, sustainability, } \\
\text { conserve moisture and groundwater } \\
\text { sources, at negligible costs }\end{array}$ & $\begin{array}{l}\text { Europe's average costs of } \\
\text { micro-irrigation ranges from } \\
\text { US } \$ 416-950 / \text { hectare as well as } \\
\text { endangers biodiversity }\end{array}$ \\
\hline
\end{tabular}


That being said, it is difficult to assess to what extent EbA are being integrated and mainstreamed in development and climate policies. There are only a few studies available demonstrating EbA internalization in multi-level policy contexts [32,42]. Assessments demonstrated that EbA is still a peripheral adaptation component [32], seen as an environmental sub-issue [42] and predominant in the industrialized nations [43]. In the absence of country level studies, the findings could not be verified in a national policy context and, therefore, potential gaps, challenges and entry points remain unexplored. Likewise, little is known about the degree to which EbA approaches are already integrated into policies and practices and how best it could be integrated [44]. Local government entities such as municipalities have a pivotal role in implementing EbA through wider community participation leading to sustainable adaptation [42]. However, the role of national policies and the policymaking process are fundamentally important to provide overarching guidance to these local development adaptation practices.

On this basis, the paper firstly assesses the extent of EbA mainstreaming at different policy-making level and secondly discusses gaps and challenges in identifying entry points for further levels of ESS mainstreaming. Bangladesh, one of the most vulnerable countries to climate change impacts, is selected as a case study. A number of policies of Bangladesh representing different policymaking levels are examined using a hybrid policy-mainstreaming framework. The paper is organized as follows. Section 2 discusses the framework for analyzing the current level of mainstreaming, Section 3 discusses materials and methods, Section 4 presents results acquired from the assessment, Section 5 discusses current gaps and challenges of mainstreaming so that entry points can be addressed, and Section 6 provides a set of recommendations based on the findings of the research.

\section{Mainstreaming into the Policy Process}

In order to answer the pressing needs of integrating EbA into the policy process, "mainstreaming" appears as the most sought and preferred way. Mainstreaming in this context can broadly be defined as the inclusion of EbA considerations into development and climate policies and practices to influence the dominant paradigm for bringing transformative changes [44-46]. Mainstreaming EbA into policy promotes integrated approach to climate change impacts and can robustly address both the climatic extreme events and sustainability issues [47]. In the context of EbA to climate change, the key purpose of "mainstreaming" is to internalize the goals of DRR, ensure healthy and productive ecosystems and promote "no-regret" adaptation practices as part of overall development interventions [39,48-50]. The concept of "mainstreaming", in the absence of a proper theory of integration, attempts to answer two questions: (i) to what extent a certain concept, e.g., EbA is integrated; and (ii) how systematic integration is possible.

There are normative, operational and strategic factors that lead to mainstream certain issues, e.g., EbA at the policy process [44,51]. Generally, mainstreaming can occur at two different levels: (i) vertical mainstreaming at top strategic levels such as political, national policy and regulating level integrate issues through policies and/or regulations; and (ii) horizontal mainstreaming at less powerful policy levels such as executive organizations that integrate issues at ground operations, programs and working structures while implementing projects $[17,42,44,47,51]$. This paper argues that the EbA mainstreaming should occur at both levels so policies and actions can complement each other through experiences, learning, knowledge and practices. That is why it is also essential to analyze mainstreaming of both levels so that a comprehensive picture can be drawn.

These mainstreaming strategies and norms can be operated on a policy cycle divided into a series of stages: (i) agenda setting; (ii) policy formulation; and (iii) implementation and monitoring [52-54]. There is no normative guidance to separate governance agencies and entities according to the policy cycle stages. However, the agenda setting stage consists of problems, conflicts, emerging global and national issues and political will [55]. The policy formulation stage develops legislative, regulatory and programmatic directions and polices to address the problems. The policy implementation stage formulates implantation guidelines and allocates necessary resources to implement the policies. 
Therefore, policy mainstreaming quintessentially means that EbA considerations effectively need to take place at all three stages horizontally and/or vertically to either blend existing policies into a single policy or incorporate the necessary concerns into existing ones [55]. At the same time, the investigation of policy cycle also explores how different mainstreaming norms and strategies can effectively fit with different levels to open-up entry points for further levels of mainstreaming [51]. Figure 1 shows the combined analytical and methodological framework of the paper. It details the different stages of a policy making cycle and how these stages interact with the vertical and horizontal mainstreaming process with special reference of the case study: policies of Bangladesh.

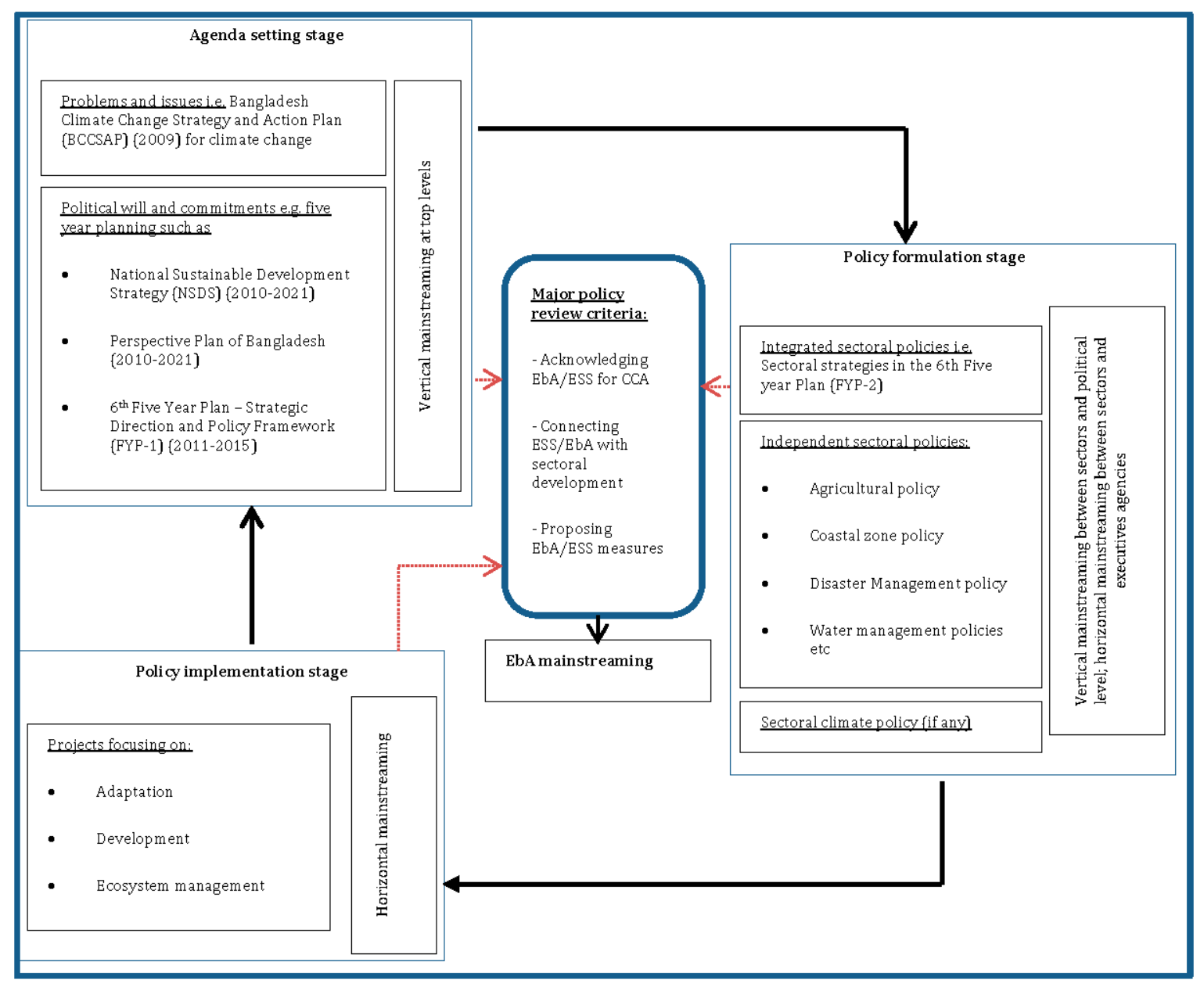

Figure 1. Combined analytical and methodological framework of the paper.

\section{Materials and Methods}

\subsection{Case Study}

The paper reviews a range of development, climate and adaptation policies of Bangladesh across policy-making cycles (Figure 1). Bangladesh is defined as one of the most vulnerable countries to climate change impacts [45], and, as a response, Bangladesh has now developed significant national capacities and has developed a number of national and sectoral climate change adaptation and resilience policies and guiding strategies [56]. Despite this progress, climate change impacts are expected to be intensified in future with significant impacts on agriculture, livelihood, economy and other sectors in Bangladesh [57-59]. Moreover, increasing population, urbanization and development pressures are putting extreme burden on its limited stock of natural capitals and fragile ecosystems leading to unsustainable use of ecosystems and its resources [60]. The case of Bangladesh can be 
very interesting given that it has to adapt with climatic disasters, continue economic development while maintaining and enhancing ecological sustainability using its limited financial, technological and environmental resources. In this context, EbA measures can be even more applicable because of its capacities to connect the fundamental cornerstones of sustainability, i.e., DRR, CCA, development and ecosystem in a cost-effective manner [21,61]. Therefore, it is crucial that policy-making processes in Bangladesh will adequately consider $\mathrm{EbA}$ in national and sectoral adaptation and development policies and pave the pathways of mainstreaming.

\subsubsection{Agenda Setting Stage}

Four national development and climate change policies which underline the nation's political vision and guidance towards development and climate change were selected for review: (i) Perspective Plan of Bangladesh (2010-2021); (ii) National Sustainable Development Strategy (NSDS) (2010-2021); (iii) 6th Five Year Plan-Strategic Direction and Policy Framework (FYP-1) (2011-2015); and (iv) Bangladesh Climate Change Strategy and Action Plan (BCCSAP) (2009). The contents of the policies were reviewed and analyzed following the criteria adopted from $[7,62]$ :

- $\quad$ Evidence of acknowledgement of ESS approach for CCA.

- Evidence of clear sectoral links between ESS and CCA.

- Proposition of ESS based approaches to CCA.

\subsubsection{Policy Formulation Stage}

At policy formulation stage, two types of polices were reviewed, firstly, 6th Five Year Plan Bangladesh—Sectoral Strategies, Programme and Policies (FYP-2) (2011-2015) and, secondly, independent sectoral development plans where EbA can be more instrumental in building adaptive capacities such as forestry, urban, agriculture, coastal, livestock and fisheries, biodiversity, water, DRR, wetland, and were selected for review. It is worth mentioning that sectoral plans prepared before 2005 were not considered for review since those are relatively old, their duration about to expire and could not consider the essence of the MEA published in 2005. In Bangladesh, there is no separate policy for wetland management and urban development; many sectors do not have updated sectoral policies such as forest policy (1994), water management policy (1999), fisheries policy (1998), biodiversity policy (2004) and landuse policy (2001); whilst coastal zone policy (2005), national agricultural policy (2013), DRR policy (2013) and livestock policy (2008) are relatively recent. The major considerations followed in reviewing sectoral policies are as follows:

- Updated sectoral policies (2005 and later).

- Sectoral policies acknowledging ESS role for sectoral adaptation.

- Evidences of clear sectoral strategies for ESS based CCA.

- Evidences of ESS based programs, projects and actions.

\subsubsection{Policy Implementation Stage}

At the policy implementation stage, the overall nature of 329 CCA projects such as types and objectives of the projects, investment priorities and sectoral priorities were reviewed. Those projects were approved by the Climate Change Trust Fund (CCTF), which itself is a flagship adaptation project of Bangladesh to implement priority adaptation projects. The major considerations for reviewing the projects are as follows:

- $\quad$ Evidence of specific and intentional ESS projects.

- Evidence of ESS application in priority sectors.

- Evidence of ESS investment for projects. 


\section{Results}

\subsection{Agenda Setting: National Policies}

Four policy documents representing development and climate policies of Bangladesh are reviewed. The reviewed policies underscore the urgency of a climate resilient society and the importance of ESS to achieve it within its limited scope of articulation. Although the relevant terminologies, e.g., "ecosystem services", are only mentioned once in all four documents, there are strategic visions appear to undertake $\mathrm{EbA}$ approaches as a resilient building mechanism. Table 2 provides a summary of the contribution of the major national development and climate policies.

Table 2. Comparative content analysis of major policy documents.

\begin{tabular}{|c|c|c|c|c|}
\hline \multirow[b]{2}{*}{ Name of the Policies } & \multirow{2}{*}{$\begin{array}{l}\text { Major Contribution and Focus in } \\
\text { Relation to EbA }\end{array}$} & \multicolumn{3}{|c|}{ Criteria of Assessment } \\
\hline & & $\begin{array}{l}\text { Evidences } \\
\text { of ESS }\end{array}$ & $\begin{array}{l}\text { Evidences of } \\
\text { Sectoral ESS }\end{array}$ & $\begin{array}{l}\text { Evidences of } \\
\text { ESS Proposition }\end{array}$ \\
\hline $\begin{array}{l}\text { Perspective Plan of Bangladesh } \\
(2010-2021)\end{array}$ & $\begin{array}{l}\text { Environment management, conservation, } \\
\text { CCA and DRR are prioritized without } \\
\text { mentioning ESS. Hard adaptation is } \\
\text { mentioned without further detailing. }\end{array}$ & + & + & NM \\
\hline $\begin{array}{l}\text { National Sustainable } \\
\text { Development Strategy } \\
(2010-2021)\end{array}$ & $\begin{array}{l}\text { Preservation of ecosystems, CCA and } \\
\text { DRR is seen as a major vision for } \\
\text { sustainable development. Environment } \\
\text { sectors proposes ESS based strategies }\end{array}$ & ++ & ++ & + \\
\hline $\begin{array}{l}\text { 6th Five Year Plan-Strategic } \\
\text { Direction and Policy Framework } \\
(2011-2015)\end{array}$ & $\begin{array}{l}\text { Forestry sector provided details strategies } \\
\text { could be benefited for ESS, CCA and DRR. } \\
\text { No ESS proposals for CCA and DRR }\end{array}$ & + & ++ & + \\
\hline $\begin{array}{l}\text { Bangladesh Climate Change } \\
\text { Strategy and Action Plan (2009) }\end{array}$ & $\begin{array}{l}\text { Government climate change policy. ESS } \\
\text { related proposals available although } \\
\text { many potentials areas left out }\end{array}$ & ++ & ++ & ++ \\
\hline
\end{tabular}

The presence of the criteria in the contents is expressed as "very strong and/or directly mentioned (+++)", "strong and/or indirectly mentioned $(++)$ " and "minor and/or can be achieved as byproduct $(+)$ ". NM means "not mentioned".

The three national development policies vary in context, size, vision, and scope. The first two, i.e., the Perspective Plan of Bangladesh (2010-2021) and the NSDS (2010-2021), are generally seen as guiding principles for national development whilst the 6th Five Year Plan (FYP-1)-Strategic Direction and Policy Framework (2011-2015) is generally a working document to provide operational objectives and strategies to achieve those principles. Therefore, the extent and consideration of EbA in these documents also considerably differ. Table 2 shows that all reviewed national policies provide some degree of focus on $\mathrm{EbA}$ approaches. Most of the policies do not provide any apparent connection between ESS and CCA, nonetheless provided objectives, strategies and targets for ecosystem management which is vital for grounding EbA.

The Perspective Plan of Bangladesh (2010-2021) [63] frames climate change adaptation as one of its main development agendas. Among the long list of strategies, there is no direct reference of $\mathrm{EbA}$, however, strategies such as biodiversity conservation and enhancement, improving river navigability, and afforestation are included as development directions for environment, climate change and disaster management. Moreover, principles such as climate tolerant agricultural varieties, greater use of rainwater, and extension of the coastal green belt can be seen as a stepping stone towards EbA. Therefore, despite the apparent omission, such ecosystem centered principles can provide an enabled environment for greater uptake of $\mathrm{EbA}$ at different sectors and policy stages.

The NSDS [64] recommends a broad set of strategies for grounding the broader development goals set in the Perspective Plan of Bangladesh. The NSDS evidently made an attempt to undertake the aura of EbA approaches in many sectors, if not all, most notably agriculture and rural development, urban management, environment planning and DRR and articulated a number of EbA propositions, which, in effect, can enhance the ecosystem services, increase ecosystem's health, reduce disaster risks and increase adaptive capacities. Most notable propositions include, among others; (i) restoration 
of surface water, wetland ecosystems and river through ecosystem based approaches; (ii) enhancing forest and forest biodiversity, conserving wetland areas and biodiversity; (iii) expansion of coastal greenbelt and afforestation; (iv) reducing soil loss, enhancing fertility and land management through plantation; (v) coastal resource management; and (vi) preparing ecosystem based DRR management plan. Among 10 urban management strategies ecosystem based detail area planning, greening and maintaining natural ecosystems are the three strategies to be highlighted. Similarly, the agriculture and rural development sectors are also advised to follow agro-ecological zoning and calendar for agricultural production, developing climate tolerant crop varieties, increasing aquatic biodiversity and wetland management for fisheries development and encouraging climate tolerant livestock for ecologically hostile areas.

In contrast to the NSDS, the 6th Five Year Plan (FYP-1) - Strategic Direction and Policy Framework (2011-2015) [65] articulated a more conventional development approach where EbA related approaches is seen as a mere environmental concern. The policy is developed within the growing global influence of integrating $\mathrm{EbA}$; therefore, greater onuses of incorporating such concerns might be expected [66]. The section on environment and the related sub-sections outline the objectives of protecting the natural resource base, conserving and improving biodiversity, extending forest coverage, adapting to climate change and reducing disaster risk during the plan's time period by 2016. However, only the forestry sub-sector provided a handful of EbA strategies such as coastal greenbelts (six programs out of a total of 14) which can potentially generate a wide range of ecosystem services such as livelihood opportunities, bio and agro diversity and DRR [65]. On the contrary, there is no EbA strategy proposed for CCA among its 36 targets. It is worth mentioning that the adaptation strategies in the 6th FYP-1 are mostly identical to the Bangladesh Climate Change Strategy and Action Plan (BCCSAP) of 2009.

The second section of the agenda setting stage is the "specialized" plan for climate change. The BCCSAP proposed 151 hard and soft adaptation actions under six major themes and 44 programs without any reference of the term "ecosystem services" of "EbA" [67]. Among the lost list of actions, 19 actions such as institutional development (five actions), afforestation (five actions), food security (three actions), river management (three actions), and ecosystem management (three actions) could be flagged-out with EbA potentials.

The policy documents of the agenda setting stage fundamentally adhere to the principles of climate smart sustainable development and propose varied degrees of EbA favoring goals strategies, actions and targets. The three pieces of national strategic documents demonstrate Bangladesh's political willingness and commitments towards integrated EbA, CCA and DRR. The BCCSAP, despite leaving many of the ESS potential sectors untouched, e.g., DRR, urban management, etc., underscores the commitments towards EbA. Although no documents are specific in connecting CCA and EbA directly, the suggested strategies could be capitalized as a point of departure for widespread EbA consideration. However, it is mostly the responsibility of each respective sector to implement the strategies and therefore sectoral planning carries the central responsibility $[63,65]$.

\subsection{Policy Formulation Stage: Sectoral Policies}

The policy formulation stage is entitled to carry the responsibilities of developing EbA measures at the sectoral stage for practical implementation [52]. As mentioned earlier, only four sectors, i.e., DRR, agriculture, coastal and livestock sectors, have updated sectoral policies made after 2005 while the other sectors effectively depend on the 6th Five Year Plan (FYP-2) Bangladesh-Sectoral Strategies, Programme and Policies (2011-2015) since their respective sectoral policies become fairly old. There is no separate policy or separate section in the FYP-2 available for wetland. A general overview of the contents of sectoral policies regarding ESS is shown in Table 3. 
Table 3. ESS consideration at sectoral policies.

\begin{tabular}{|c|c|c|c|c|c|}
\hline Sectors & Name of the Policies & Major Connection with ESS and CCA & $\begin{array}{l}\text { Evidence of } \\
\text { ESS }\end{array}$ & $\begin{array}{l}\text { Evidence of Sectoral } \\
\text { ESS Links }\end{array}$ & $\begin{array}{c}\text { Evidence of ESS } \\
\text { Propositions }\end{array}$ \\
\hline \multirow[t]{2}{*}{ Disaster } & $\begin{array}{l}\text { National Disaster } \\
\text { Management plan } 2014\end{array}$ & $\begin{array}{ll}\text { - } & \text { No EbA action or } \\
\text { program proposed } \\
\text { - } \quad \text { Institutional and structural } \\
\text { aspects of DRR is the main focus }\end{array}$ & NM & NM & NM \\
\hline & FYP-2 DRR policy 2011 & - No ESS strategy is proposed & NM & NM & NM \\
\hline \multirow[b]{2}{*}{ Agriculture } & $\begin{array}{l}\text { National Agriculture } \\
\text { policy } 2013\end{array}$ & $\begin{array}{l}\text { - } \quad \text { No direct EbA proposal } \\
\text { Climate tolerant varieties and } \\
\text { natural resource, e.g., water } \\
\text { management are emphasized }\end{array}$ & + & + & + \\
\hline & $\begin{array}{l}\text { FYP Agriculture } \\
\text { policy } 2011\end{array}$ & $\begin{array}{l}\text { - Crop production using } \\
\text { agro-ecological zoning and } \\
\text { improved crop varieties } \\
\text { are stressed } \\
\text { - } \quad \text { Extensive research focus on } \\
\text { ecosystem based agriculture for } \\
\text { adaptation including soil, water } \\
\text { and rainfed agriculture }\end{array}$ & NM & + & ++ \\
\hline Livestock & $\begin{array}{l}\text { National Livestock } \\
\text { Development Policy } \\
2007 \text { \& FYP-2 policy } 2011\end{array}$ & - No proposal for EbA and CCA & NM & NM & NM \\
\hline Coastal & Coastal Zone Policy 2005 & $\begin{array}{l}\text { Without direct reference of ESS, } \\
\text { ESS favored proposals for } \\
\text { agriculture, natural resources, } \\
\text { ecosystem related management }\end{array}$ & ++ & +++ & +++ \\
\hline Urban & FYP-2 Urban Policy 2011 & - No proposal for ESS and CCA & NM & NM & NM \\
\hline Forestry & FYP-2 Forestry policy & $\begin{array}{l}\text { Proposals for extending coastal } \\
\text { greenbelt, social forestry and new } \\
\text { plantation for CCA, DRR, } \\
\text { biodiversity, livelihood, soil and } \\
\text { watershed management }\end{array}$ & + & + & ++ \\
\hline Water & FYP-2 Water policy & $\begin{array}{l}\text { - Restoration of rivers and basin } \\
\text { wide water resource management }\end{array}$ & ++ & ++ & + \\
\hline Biodiversity & $\begin{array}{l}\text { FYP-2 Biodiversity } \\
\text { policy }\end{array}$ & $\begin{array}{l}\text { - No specific biodiversity proposal } \\
\text { except forest expansion }\end{array}$ & NM & NM & NM \\
\hline Fisheries & FYP-2 Fisheries policy & - No proposal for ESS and CCA & NM & NM & + \\
\hline Landuse & FYP-2 landuse policy & - No proposal for ESS and CCA & NM & NM & NM \\
\hline Wetland & No policy & $\begin{array}{l}\text { - Sporadic proposals embedded in } \\
\text { other sectors }\end{array}$ & NM & NM & NM \\
\hline
\end{tabular}

The presence of the criteria in the contents is expressed as "very strong and/or directly mentioned $(+++)$ ", "strong and/or indirectly mentioned (++)" and "minor and/or can be achieved as byproduct $(+)$ ". NM means "not mentioned".

Similar to the national policies, no direct policies or strategies are mentioned in the FYP-2 to promote $\mathrm{EbA}$ or integrated development and adaptation practices highlighting ecosystem management [68-71]. Table 3 reflects that the majority of the sectors except agriculture, forestry, coastal and water management fail to connect their respective sectoral objectives with EbA philosophies, let alone proposing ESS strategies. Sectors such as DRR, biodiversity, urban development, fisheries, land-use and wetland are arguably the major hotspots for EbA applications, and even the newer policy strategies of Bangladesh overlook such potentials. Fisheries management strategies of the FYP-2 outline two strategies for conserving fish habitat and wetland are in line with EbA approaches for fisheries, aquatic biodiversity and wetland [68].

In contrast, agriculture, coastal, forestry and water sectors reflected better EbA awareness in proposing their sectoral strategies in a varied extent and importance [68-70,72]. National Agriculture Policy of 2013 together with FYP-2 proposed 209 development actions and strategies under 13 major sectors, and only 13 of them are relevant to EbA, e.g., expansion of climate tolerant varieties, promoting ecosystem based agriculture, soil management, land reclamation, managing water and other natural 
resources for sustainable agriculture [69]. The Coastal Zone Policy of 2005 proposed a total of 94 sectoral strategies under eight major themes and 27 strategies can be linked to ecosystem and sustainable coastal resources management that can appear as adaptation options [70]. Major strategies include afforestation, tidal river management, rainwater harvesting, saline tolerant crops and conservation of forest and marine reserves [70]. The water management sector of the FYP-2 proposed $11 \mathrm{EbA}$ favored strategies to achieve its 21 objectives. Among them, strategies such as river dredging, river basin management and land reclamation could potentially assist the adaptation objectives of increasing river's capacity, flood management, salinity prevention and irrigation management [68]. The forestry sector; a subsector of environment management in the FYP-2 has seven EbA favored strategies to enhance ESS and adaptation capacities in its total 25 major development objectives and strategies including afforestation, coastal greenbelt, watershed management, soil conservation and forest biodiversity management [68].

The analysis of sectorial polices can be summarized as three useful observations: (i) consideration of EbA; (ii) importance of EbA; and (iii) nature of EbA strategies. Firstly, on a positive note, despite omission from many potential sectors, EbA strategies and directions are included in certain sectors, though indirectly, and without connecting to CCA. These strategies can still provide multiplying benefits to society through provisioning services, e.g., food production and security, energy provision, and water security; regulating services, e.g., DRR; and eventually contribute to increase societal adaptive capacity $[15,73]$. Secondly, compared to other development strategies, the proposed EbA strategies are marginally considered and hardly elaborated. Excluding the coastal management sector, only 24 sectoral strategies can be linked to EbA, which is only four percent of total 642 strategies. Thirdly, very few of the identified EbA strategies provide any clear direction of implementation and are often very headlinesque, for example "water conservation for irrigation" [68]. Moreover, many sectors separately propose specific hard CCA actions such as embankment and dyke construction, which underlines the lack of integrated adaptation thinking at the policy formulation stage.

\subsection{Policy Implementation Stage: Climate Change Adaptation Projects}

One way of realizing the implications of national and sectoral policies at the implementation stage is analyzing projects, specifically adaptation projects. There is no official data available about the number of climate change adaptation projects currently being implemented in Bangladesh. The Climate Change Trust Fund (CCTF) is a government-funded project mainly aimed to implement government priority adaptation projects highlighted in BCCSAP through different ministries and sectors. CCTF, as of December 2015, has 329 approved projects for implementing through different government ministries, agencies and bodies [74]. Among the 329 projects, 38 projects are related to ecosystem management and activities, which can enhance the flow of ecosystem services, strengthen ecosystem's resilience and increase community's adaptive capacities. Analysis of the contents of the 38 projects reveals that none of the projects are directly aiming to promote EbA and ESS management, rather are aiming to achieve different objectives, e.g., increasing river navigability, however, can potentially generate benefits of EbA.

The 38 ESS projects can be classified in seven major groups; river dredging for flood and water management (14 projects), forestry for disaster and livelihood management (eight projects), biodiversity management for improving ecosystem's health (four projects), food security through climate tolerant varieties and eco-agricultural technologies (five projects), environment management (one project) and fisheries management for improving indigenous species (one project) [74]. The majority of these projects also simultaneously aim to address DRR, agricultural productivity and livelihood adaptation as one of the outcomes. Thematically, 19 of the 38 projects primarily address DRR activities, 10 projects target agricultural and agro-ecosystem development, and nine projects are concerned with livelihood development, e.g., economic, fisheries and livestock. There are no projects related to landuse, urban or wetland management by CCTF funding. 
CCTF's adaptation projects, in general, are clearly favoring hard adaptation approaches (155 projects with very strong focus of structural infrastructure such as embankment, dyke and shelter construction). While the structural approach is still necessary, a gradual shift towards EbA approach would have surely offered certain long term benefits such as cost effectiveness, avoiding mal-adaptation, community participation and livelihood development [1,14].

In the context of Bangladesh, the EbA approach received considerable attention at the top national development and climate change policies, but gradually lost its momentum at sectoral and project levels. Since there is little motivation and commitment to $\mathrm{EbA}$ at the policy formulation stage, a very small proportion of ESS projects and budgets are available for the implementation stage. For example, \$235.2 million of CCTF's \$279 million budget during 2009-2015 was allocated for non-EbA projects focused on different infrastructural development (Figure 2). At the same time, more than one third of the tiny ESS budget of $\$ 15.9$ million was allocated for river dredging and only $\$ 26.78$ million was allocated for forestry, biodiversity, and agriculture related ESS projects together over the 6 year period (2009-2015). CCTF also gradually approved fewer ESS projects against a bourgeoning number of total projects since 2009. Figure 3 shows that, in 2009, 31.25\% project could be categorized as ESS, however, significant decreases of ESS projects are evident for successive years. For the fiscal year 2014-2015, 78 projects were approved for funding with not a single ESS project approved [74].

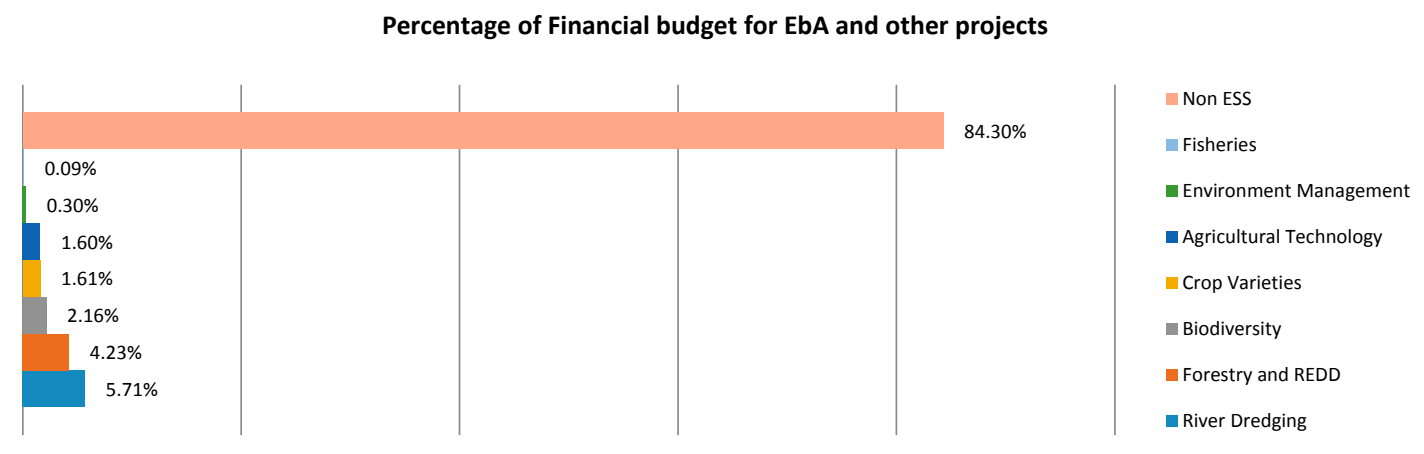

Figure 2. Budget for EbA and other adaptation projects.

Approved EbA projects between 2009-2015

Total $\square$ ESS

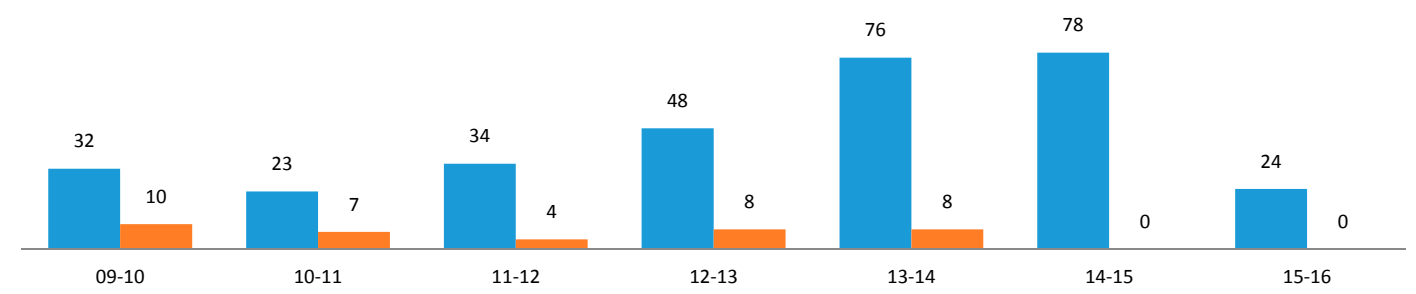

Figure 3. Approved number of EbA and Non-EbA projects between 2009 and 2015.

\section{Discussion}

The agenda setting stage of policy making, amongst other national development policies and the national climate change policy, demonstrated somewhat incomprehensive but vital bearing and commitment to embrace EbA approaches for adaptation and development. The Perspective Plan of Bangladesh and especially the NSDS indicate a fundamental shifting of national development philosophies towards a greener approach emphasizing the ecosystem's role for sustainable development than the earlier predominant economic-centered vision (e.g., Poverty Reduction Strategy Papers 2009) [63,64]. Thus, despite an apparent missing link among ecosystem, CCA, and development, 
the documents demonstrated commitments to enhancing the ecosystem's roles in sustainable development, which can subsequently promote $\mathrm{EbA}[63,64]$. EbA considerations are not as visible as someone might expect in the FYP-1, however, it mainly proposes BCCSAP to plan for a climate resilient future. Although, increasing EbA considerations are evident in the BCCCSAP, there are many untapped potentialities remain unexplored, for example, no ESS centric DRR and urban management proposals. However, in conjunction with national development policies, a clear point of departure is visible. The results at the agenda setting stage, thus, can be seen as an indication of improved vertical mainstreaming of ecosystem approaches among the key and influential policy making bodies and actors for national development, i.e., ministries and political leadership.

Results reveal a significant discontinuation of EbA consideration at both policy formulation and implementation stages or horizontal mainstreaming level. In the current policy making system in Bangladesh, much of the sectoral development work is carried out by respective ministries and associated sectors through sectoral strategies and projects $[75,76]$. Analysis of most vulnerable and pertinent sectors to EbA, i.e., agriculture, coastal, DRR, forestry, water, biodiversity, urban, wetland and livelihood sectors, revealed rather an unimpressive picture in terms of EbA mainstreaming. Except for the coastal sector, all other sectoral development policies trivially reflected the prospects of $\mathrm{EbA}$, and, in many instances, completely ignored them. Adaptation projects at the implementation level, likewise, demonstrated even more conservative adaptation approaches preferring to invest more in hard approaches overlooking the EbA potentials. In addition, climate change adaptation and ecosystem approaches are seen as competing elements, and sectors, rather than complementing one another, which is identified as one of the major challenges to promoting EbA [77].

The findings of the review could briefly be summarized from three main perspectives. Firstly, climate change adaptation in Bangladesh is overwhelmingly viewed as a structural and technical approach ignoring its socio-cultural attachments with human and nature [46,78]. As a result, EbA approaches are still an underappreciated measure throughout the decision making stages. Secondly, the findings highlight vast differences in adaptation priorities and understanding at national and sectoral level $[79,80]$. EbA is certainly not a top priority of sectoral adaptation activities, evident in sectoral policies and projects. Thirdly, it appeared that policy makers at both national and sectoral levels remain uninformed and unaware regarding the potential of the EbA approach $[14,81]$. This is why potential ESS scopes, e.g., DRR, urban and water, are often ignored or undervalued.

Globally, there are clear research gaps in understanding the governance and other social-ecological challenges to uptake and implement EbA approaches. Much of the research is still very much skewed to developing and evaluating different $\mathrm{EbA}$ techniques and technologies [82]. Therefore, the rarity of the published literature made it difficult to explain the reasons behind the slower pace of EbA mainstreaming. Horizontal mainstreaming, which is important to bring changes at sub-national and local levels, occurs at a considerably slower scale and pace than vertical mainstreaming at the national level. Reviews of existing adaptation literature on Bangladesh mainly pointed out three structural flaws of current adaptation policy making: (i) adaptation ideologies; (ii) policy making process; and (iii) awareness and mainstreaming.

\subsection{Adaptation Ideologies}

Historically, the adaptation strategies and projects in Bangladesh demonstrated pure preference of hard adaptation such as embankment and dams for flood management started in 1960 [83,84] and play key roles in defining adaptation ideologies, policy agenda $[84,85]$. Hard adaptation approach, since then, became a part of adaptation culture and ideology of major institutions, e.g., rural development and water resource ministries. Likewise, sectoral planning is still mostly dominated by hard structural approaches [86]. For example, water resource and rural development ministries mostly favored hard approaches, which are evident in their respective sectoral plans and projects (see Figure 4). 


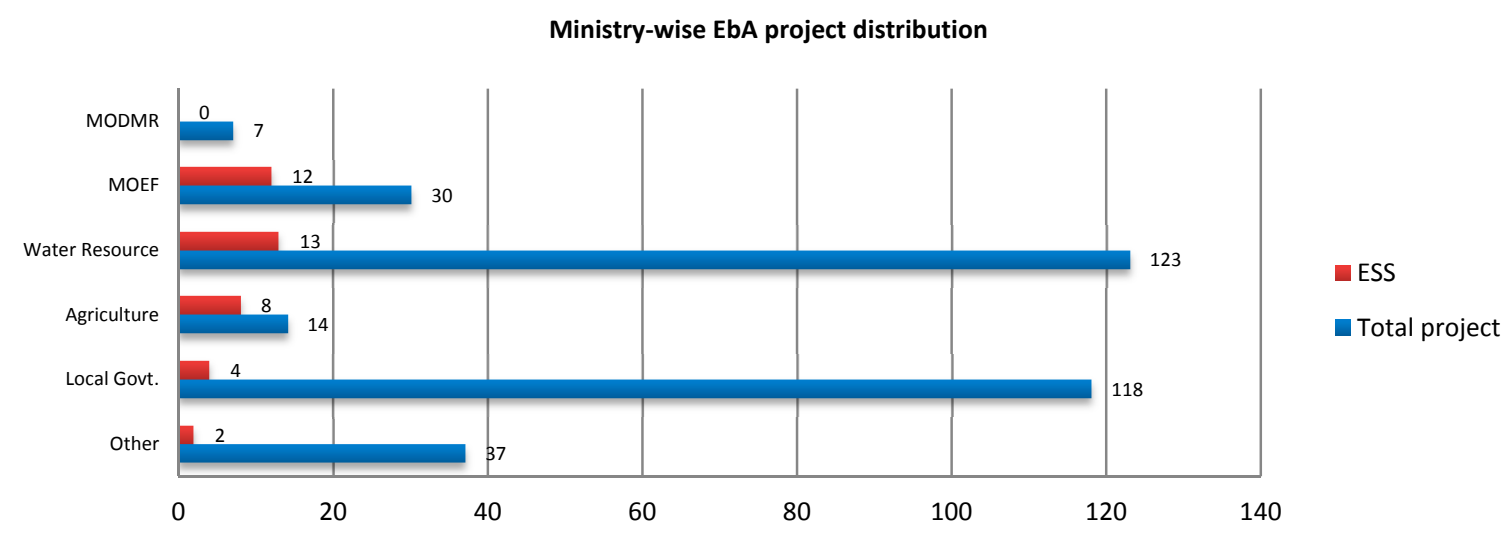

Figure 4. Ministry wise EbA project distribution.

\subsection{Policy Making Processes}

Policy making processes in Bangladesh are traditionally top-down owing to its long colonial past and mostly driven by the experts and bureaucrats $[75,87]$. Public and stakeholder participation in policy making processes are still significantly poor despite recent the increase in making "deliberate" policy outcomes $[87,88]$. The national development and climate change polices are credited for public consultation in its development phases with non-governmental stakeholders. When it comes to developing sectoral policies and plans, the ministries are responsible for policy formulation, planning, evaluation and implementation lead by experts and sectoral bureaucrats [88]. Expert driven (sectoral) policies are often blamed for lack of multidisciplinary inputs, stakeholder and local participation $[47,89,90]$. Additionally, bureaucratic planning and policy in Bangladesh gradually lost objectivity, grew in reluctance to engage stakeholders and is undermined by excessive political influence [75]. As a result, sectoral policies are mostly following traditional norms, forms and practices to avoid tussling with established practices and power structures $[75,91]$. Furthermore, the structural anomalies, poor human resources management, corruption and lack of accountability of current bureaucracy also lead to steady decline of policies [34,75].

\subsection{Institutional Capacity to Mainstreaming of Climate Change}

Increasing capacity and awareness of climatic risk and knowledge of adaptation at institutional level are important cornerstones for sustainable resilience planning [17,92]. Climate change is still viewed as an environmental problem and the necessary mainstreaming of climate change is yet to happen in Bangladesh, let alone mainstreaming of ESS approaches $[45,88,93]$. The Ministry of Forests and Environment (MOEF) and Ministry of Agriculture are much closer to climate change impacts and regularly participate in climate change issues nationally and internationally. This is why their projects often acknowledge the role of alternative approaches such as ESS as well as have a relatively higher proportion of EbA projects compared to other ministries (see Figure 4). At the same time, frequent disasters, e.g., cyclone, flood and river erosion force the responsible organizations to compete over priorities and undertake short term priorities such as constructing concrete dams and embankments rather than long term and alternative approaches such as EbA. Analysis of CCTF's projects revealed that Ministries such as Water Resources (MoWR), Local Government and Ministry of Disaster Management and Relief (MODMR) are occupied with structural contingency projects such as building shelter and embankments (see Figure 4).

Therefore, the findings of the paper arrive at the similar conclusion of the relevant literature of adaptation governance, e.g., $[7,16,26,94]$ that the EbA approach is very much a nascent concept at the adaptation policy level, especially in the context of a developing country. More research is necessary addressing EbA governance, e.g., [14,17,85] to establish the underlying causes of such low levels of (horizontal) mainstreaming of EbA. From the mainstreaming perspective, the findings also signify the 
important statement that the current development and adaptation policies and practices of Bangladesh are yet not very favorable for materializing a holistic and integrated concept of EbA.

Based on the findings of the policy review, the four important priorities for EbA mainstreaming could be identified. Firstly, communicating climate knowledge and learning across scales to improve horizontal mainstreaming through increasing inter and intra organization cooperation and participation for developing sectoral plans and adaptation projects. Secondly, increasing the learning and adaptive capacities of the key sectors and organization so that state-of-the-art ideologies and technologies can be transferred for action. Thirdly, update sectoral policies in light of global scientific understanding, learning and experiences as well as to ensure legitimate back-up for the policies for better implementation [17]. Fourthly, EbA policies across scale will necessarily address the poor and vulnerable communities since the distribution of ESS are often influenced by the social and political elites [95].

\section{Conclusions}

Ecosystem and ecosystem services are fundamental for sustaining and building resilience to climate change impacts most notably through livelihood development, urban resilience, agricultural productivity and disaster risk reduction (DRR). Hence, ESS based adaptation approaches (EbA) increasing in importance in international and national adaptation discourses. Because of the close interdependence, $\mathrm{EbA}$ is possibly the most favorable pathway for conceiving and implementing a no-regret adaptation approach along with sustainable development. Vertical and horizontal mainstreaming of EbA both at development and climate change adaptation will provide an extra edge for policy makers for inclusive development, resource efficiency and, above all, sustainability.

The paper reviewed national development and climate policies, sectoral development polices and CCTF's adaptation policies to understand and evaluate EbA mainstreaming. The findings showed that $\mathrm{EbA}$ is still a fringe adaptation component at different policy and implementation levels. Current $\mathrm{EbA}$ mainstreaming and integration in the national policy process offer the somber picture, especially at the horizontal level involving sectoral and implementation level that the possibilities of EbA are largely ignored for the majority of potential sectors over an evident preference for structural adaptation. Long-standing structural favored adaptation ideologies, isolated and bureaucracy dependent sectoral adaptation decision-making and lack of mainstreaming awareness at different policy-making levels are, among others, formidable challenges to overcome to promote ecosystem approaches of climate change adaptation and development.

Acknowledgments: The authors are grateful to the two anonymous reviewers for their very constructive comments to improve the manuscript. The authors are also acknowledging the financial support from the Technische Hochschule Köln, the University of Trier and the International Centre for Climate Change Adaptation and Development (ICCCAD) for this open access publication, as well as, Centers for Natural Resources and Development (CNRD) network for providing the research opportunity.

Author Contributions: Nazmul Huq and Antje Bruns conceptualized the research idea; Nazmul Huq prepared the primary text and analyzed the data; and Antje Bruns, Lars Ribbe and Saleemul Huq edited, reviewed and finalized the text.

Conflicts of Interest: The authors declare no conflict of interests.

\section{References}

1. Bhatta, L.D.; van Oort, B.E.H.; Stork, N.E.; Baral, H. Ecosystem services and livelihoods in a changing climate: Understanding local adaptations in the Upper Koshi, Nepal. Int. J. Biodivers. Sci. Ecosyst. Serv. Manag. 2015, 11, 145-155. [CrossRef]

2. Huq, N. Ecosystem services for meeting sustainable development goals: Challenges and pathways. Chang. Adapt. Socio-Ecol. Syst. 2015, 2, 97-99. [CrossRef]

3. Wertz-Kanounnikoff, S.; Locatelli, B.; Wunder, S.; Brockhaus, M. Ecosystem-based adaptation to climate change: What scope for payments for environmental services? Clim. Dev. 2011, 3, 143-158. [CrossRef] 
4. Depietri, Y.; Renaud, F.G.; Kallis, G. Heat waves and floods in urban areas: A policy-oriented review of ecosystem services. Sustain. Sci. 2011, 7, 95-107. [CrossRef]

5. Munroe, R.; Roe, D.; Doswald, N.; Spencer, T.; Möller, I.; Vira, B.; Reid, H.; Kontoleon, A.; Giuliani, A.; Castelli, I.; et al. Review of the evidence base for ecosystem-based approaches for adaptation to climate change. Environ. Evid. 2012, 1, 13. [CrossRef]

6. UNFCCC. Report on the Technical Workshop on Ecosystem-Based Approaches for Adaptation to Climate Change; UNFCC: Bonn, Germany, 2013.

7. Huq, N.; Stubbings, A. How is the Role of Ecosystem Services Considered in Local Level Flood Management Policies: Case Study in Cumbria, England. J. Environ. Assess. Policy Manag. 2015, 17, 1550032. [CrossRef]

8. Costanza, R.; Pérez-Maqueo, O.; Martinez, M.L.; Sutton, P.; Anderson, S.J.; Mulder, K. The value of coastal wetlands for hurricane protection. Ambio 2008, 37, 241-248. [CrossRef]

9. Crossman, N.D.; Burkhard, B.; Nedkov, S.; Willemen, L.; Petz, K.; Palomo, I.; Drakou, E.G.; Martín-Lopez, B.; McPhearson, T.; Boyanova, K.; et al. A blueprint for mapping and modelling ecosystem services. Ecosyst. Serv. 2013, 4, 4-14. [CrossRef]

10. IUCN. Building Resilience to Climate Change Ecosystem-Based Adaptation and Lessons from the Field; Pérez, Á.A., Fernández, B.H., Gatti, R.C., Eds.; IUCN: Gland, Switzerland, 2010.

11. MEA. Millennium Ecosystem Assessment-Ecosystems and Human Well-Being: Biodiversity Synthesis; World Resources Institute: Washington, DC, USA, 2005.

12. Van Buuren, A.; Potter, K.; Warner, J.; Fischer, T. Making space for institutional change? A comparative case study on regime stability \& change in river flood management in the Netherlands \& England. Int. J. Water Gov. 2015, 3, 81-100.

13. Convention on Biological Diversity. Connecting Biodiversity and Climate Change Mitigation and Adaptation: Report of the Second Ad Hoc Technical Expert Group on Biodiversity and Climate Change; Convention on Biological Diversity: Montreal, QC, Canada, 2009.

14. Chong, J. Ecosystem-based approaches to climate change adaptation: Progress and challenges. Int. Environ. Agreem. Politics Law Econ. 2014, 14, 391-405. [CrossRef]

15. Vignola, R.; Harvey, C.A.; Bautista-Solis, P.; Avelino, J.; Rapidel, B.; Donatti, C.; Martinez, R. Ecosystem-based adaptation for smallholder farmers: Definitions, opportunities and constraints. Agric. Ecosyst. Environ. 2015, 211, 126-132. [CrossRef]

16. Jones, H.P.; Hole, D.G.; Zavaleta, E.S. Harnessing nature to help people adapt to climate change. Nat. Clim. Chang. 2012, 2, 504-509. [CrossRef]

17. Huq, N. Institutional Adaptive Capacities to Promote Ecosystem-based Adaptation (EbA) to Flooding in England. Int. J. Clim. Chang. Strateg. Manag. 2016, 8, 212-235. [CrossRef]

18. Colls, A.; Ash, N.; Ikkala, N. Ecosystem-Based Adaptation: A Natural Response to Climate Change; IUCN: Gland, Switzerland, 2009.

19. Grimsditch, G. Ecosystem-Based Adaptation in the Urban Environment. In Resilient Cities: Cities and Adaptation to Climate Change-Proceedings of the Global Forum 2010; Otto-Zimmermann, K., Ed.; Springer: Dordrecht, The Netherlands, 2011.

20. Huq, N. Small scale fresh water ponds in rural Bangladesh: Navigating roles and services. Int. J. Water 2016, $10,73-85$.

21. Travers, A.; Elrick, C.; Kay, R.; Vestergaard, O. Ecosystem-Based Adaptation Guidance: Moving from Principles to Practice; United Nations Environment Programme: Nairobi, Kenya, 2012.

22. Naumann, S.; Anzaldua, G.; Gerdes, H.; Frelih-Larsen, A.; Davis, M. Assessment of the Potential of Ecosystem-Based Approaches to Climate Change Adaptation and Mitigation in Europe; Final Report to the European Commission, DG Environment; University of Oxford: Oxford, UK, 2011.

23. Vignola, R.; Locatelli, B.; Martinez, C.; Imbach, P. Ecosystem-based adaptation to climate change: What role for policy-makers, society and scientists? Mitig. Adapt. Strateg. Glob. Chang. 2009, 14, 691-696. [CrossRef]

24. Szabo, S.; Renaud, F.G.; Hossain, M.S.; Sebesvári, Z.; Matthews, Z.; Foufoula-Georgiou, E.; Nicholls, R.J. Sustainable Development Goals Offer New Opportunities for Tropical Delta Regions. Environ. Sci. Policy Sustain. Dev. 2015, 57, 16-23. [CrossRef]

25. Munang, R.; Thiaw, I.; Alverson, K.; Liu, J.; Han, Z. The role of ecosystem services in climate change adaptation and disaster risk reduction. Curr. Opin. Environ. Sustain. 2013, 5, 47-52. [CrossRef] 
26. Doswald, N.; Munroe, R.; Roe, D.; Giuliani, A.; Castelli, I.; Stephens, J.; Möller, I.; Spencer, T.; Vira, B.; Reid, H. Effectiveness of ecosystem-based approaches for adaptation: review of the evidence-base. Clim. Dev. 2014, 6, 185-201. [CrossRef]

27. Patrick, D.M. Climate Change Adaptation for People and Nature: Climate Change Adaptation for People and Nature. Adv. Clim. Chang. Res. 2013, 3, 22-37.

28. Mercer, J.; Kelman, I.; Alfthan, B.; Kurvits, T. Ecosystem-based adaptation to climate change in caribbean small island developing states: Integrating local and external knowledge. Sustainability 2012, 4, 1908-1932. [CrossRef]

29. World Bank. Convenient Solutions to an Inconvenient Truth: Ecosystem based Approaches to Climate Change; World Bank: Washington, DC, USA, 2009.

30. Schroth, G.; Laderach, P.; Dempewolf, J.; Philpott, S.; Haggar, J.; Eakin, H.; Castillejos, T.; Garcia Moreno, J.; Soto Pinto, L.; Hernandez, R.; et al. Towards a climate change adaptation strategy for coffee communities and ecosystems in the Sierra Madre de Chiapas, Mexico. Mitig. Adapt. Strateg. Glob. Chang. 2009, 14, 605-625. [CrossRef]

31. Carabine, E.; Venton, C.C.; Tanner, T.; Bahadur, A. The Contribution of Ecosystem Services to Human Resilience A Rapid Review; Oversease Development Institute: London, UK, 2015.

32. Pramova, E.; Locatelli, B.; Brockhaus, M.; Fohlmeister, S. Ecosystem services in the National Adaptation Programmes of Action. Clim. Policy 2012, 12, 393-409. [CrossRef]

33. Guerry, A.D.; Polasky, S.; Lubchenco, J.; Chaplin-Kramer, R.; Daily, G.C.; Griffin, R.; Ruckelshaus, M.; Bateman, I.J.; Duraiappah, A.; Elmqvist, T.; et al. Natural capital and ecosystem services informing decisions: From promise to practice. Proc. Natl. Acad. Sci. USA 2015, 112, 7348-7355. [CrossRef] [PubMed]

34. Huq, N.; Hugé, J. “Greening” Integrated Water Resources Management Policies for Tackling Climate Change Impacts: A Call for Sustainable Development. In Climate Change and the Sustainable Use of Water Resources; Leal Filho, W., Ed.; Climate Change Management; Springer: Berlin/Heidelberg, Germany, 2012; pp. 173-183.

35. IUCN. The Ecosystem Approach: Learning from Experience; Shepherd, G., Ed.; IUCN: Gland, Switzerland, 2008.

36. Munroe, R.; Doswald, N.; Roe, D.; Reid, H.; Giuliani, A.; Castelli, I. Guidance on Applying the Framework for Assessing the Evidence for the Effectiveness of Ecosystem-based Approaches to Adaptation; BirdLife International, UNEP-WCMC, IIED: Cambridge, UK, 2011.

37. Munroe, R.; Doswald, N.; Roe, D.; Reid, H.; Giuliani, A.; Castelli, I.; Nathalie, D. Evidence of Effectiveness of Ecosystem-Based Approaches to Adaptation: Review of Case Studies; BirdLife International, UNEP-WCMC, IIED: Cambridge, UK, 2011.

38. Krchnak, K.M.; Smith, D.M.; Deutz, A. Putting Nature in the Nexus: Investing in Natural Infrastructure to Advance Water-Energy-Food Security; IUCN, The Nature Conservency: Bonn, Germany, 2011.

39. Huq, N.; Renaud, F.G.; Sebesvari, Z. Ecosystem based Adaptation (EbA) to climate change-Integrating Actions to Sustainable Adaptation. In Impacts World 2013: International Conference on Climate Change Effects; Potsdam Institute for Climate Impact Research: Potsdam, Germany, 2013; pp. 151-164.

40. Everard, M. Ecosystem Services Case Studies: Better Regulation Science Programme; Environment Agency: Bristol, UK, 2009.

41. Nick, D.; Brown, N.; Lusardi, J. Assessing the Potential for Mapping Ecosystem Services in England Based on Existing Habitats; Natural England: Newcastle, UK, 2014.

42. Wamsler, C.; Luederitz, C.; Brink, E. Local levers for change: Mainstreaming ecosystem-based adaptation into municipal planning to foster sustainability transitions. Glob. Environ. Chang. 2014, 29, 189-201. [CrossRef]

43. Ruckelshaus, M.; McKenzie, E.; Tallis, H.; Guerry, A.; Daily, G.; Kareiva, P.; Polasky, S.; Ricketts, T.; Bhagabati, N.; Wood, S.A.; et al. Notes from the field: Lessons learned from using ecosystem service approaches to inform real-world decisions. Ecol. Econ. 2013, 115, 11-21. [CrossRef]

44. Wamsler, C. Mainstreaming ecosystem-based adaptation: Transformation toward sustainability in urban governance and planning. Ecol. Soc. 2015, 20. [CrossRef]

45. Ayers, J.M.; Huq, S.; Wright, H.; Faisal, A.M.; Hussain, S.T. Mainstreaming climate change adaptation into development in Bangladesh. Clim. Dev. 2014, 6, 293-305. [CrossRef] 
46. Wright, H.; Vermeulen, S.; Laganda, G.; Olupot, M.; Ampaire, E.; Jat, M.L. Farmers, food and climate change: Ensuring community-based adaptation is mainstreamed into agricultural programmes. Clim. Dev. 2014, 6, 318-328. [CrossRef]

47. Ojea, E. Challenges for mainstreaming Ecosystem-based Adaptation into the international climate agenda. Curr. Opin. Environ. Sustain. 2015, 14, 41-48. [CrossRef]

48. Cowling, R.M.; Egoh, B.; Knight, A.T.; O’Farrell, P.J.; Reyers, B.; Rouget, M.; Roux, D.J.; Welz, A.; Wilhelm-Rechman, A. An operational model for mainstreaming ecosystem services for implementation. Proc. Natl. Acad. Sci. USA 2008, 105, 9483-9488. [CrossRef] [PubMed]

49. Heller, N.E.; Zavaleta, E.S. Biodiversity management in the face of climate change: A review of 22 years of recommendations. Biol. Conserv. 2009, 142, 14-32. [CrossRef]

50. Vignola, R.; McDaniels, T.L.; Scholz, R.W. Governance structures for ecosystem-based adaptation: Using policy-network analysis to identify key organizations for bridging information across scales and policy areas. Environ. Sci. Policy 2013, 31, 71-84. [CrossRef]

51. Wamsler, C.; Pauleit, S. Making headway in climate policy mainstreaming and ecosystem-based adaptation: Two pioneering countries, different pathways, one goal. Clim. Chang. 2016, 137, 71-87. [CrossRef]

52. Benson, D.; Gain, A.K.; Rouillard, J. Water Governance in a Comparative Perspective: From IWRM to a "Nexus" Approach? Water Altern. 2015, 8, 756-773.

53. UNDP-UNEP. Mainstreaming Climate Change Adaptation into Development Planning: A Guide for Practitioners; UNDP-UNEP: Nairobi, Kenya, 2011.

54. Rasul, G.; Sharma, B. The nexus approach to water-energy-food security: An option for adaptation to climate change. Clim. Policy 2015, 3062, 1-21. [CrossRef]

55. Gain, A.K.; Giupponi, C.; Benson, D. The water-energy-food (WEF) security nexus: The policy perspective of Bangladesh. Water Int. 2015, 40, 895-910. [CrossRef]

56. Nishat, A.; Mukherjee, N.; Roberts, E.; Hasemann, A. A Range of Approaches to Address Loss and Damage from Climate Change Impacts in Bangladesh; BRAC University: Dhaka, Bangladesh, 2013.

57. Huq, N.; Hugé, J.; Boon, E.; Gain, A. Climate Change Impacts in Agricultural Communities in Rural Areas of Coastal Bangladesh: A Tale of Many Stories. Sustainability 2015, 7, 8437-8460. [CrossRef]

58. Thomas, T.S.; Mainuddin, K.; Chiang, C.; Rahman, A.; Haque, A.; Islam, N.; Sun, Y.; Quasem, S. Agriculture and Adaptation in Bangladesh Current and Projected Impacts of Climate Change; International Food Policy Research Institute: Washington, DC, USA, 2013.

59. Dhakal, S.P.; Mahmood, M.N. International aid and cyclone shelters in Bangladesh: Adaptation or maladaptation? Contemp. South Asia 2014, 22, 290-304. [CrossRef]

60. Hossain, M.S.; Dearing, J. a.; Rahman, M.M.; Salehin, M. Recent changes in ecosystem services and human well-being in the Bangladesh coastal zone. Reg. Environ. Chang. 2016, 16, 429-443. [CrossRef]

61. Nel, J.L.; Le Maitre, D.C.; Nel, D.C.; Reyers, B.; Archibald, S.; van Wilgen, B.W.; Forsyth, G.G.; Theron, A.K.; O'Farrell, P.J.; Kahinda, J.-M.M.; et al. Natural hazards in a changing world: A case for ecosystem-based management. PLoS ONE 2014, 9, e95942. [CrossRef] [PubMed]

62. Barlow, J.; Moore, F.; Burgess-Gamble, L. Working with Natural Processes to Reduce Flood Risk: $R$ \& D Framework; Environment Agency: Bristol, UK, 2014.

63. General Economics Division. Perspective Plan of Bangladesh (2010-2021): Making Vision 2021 a Reality; General Economics Division (GED): Dhaka, Bangladesh, 2012.

64. General Economics Division. National Sustainable Development Strategy (NSDS); General Economics Division (GED): Dhaka, Bangladesh, 2013.

65. General Economics Division. Sixth Five Year Plan (Part 1-Strategic Directions and Policy Framework); General Economics Division (GED): Dhaka, Bangladesh, 2011.

66. Hugé, J.; Hens, L. The greening of poverty reduction strategy papers: A process approach to sustainability assessment. Impact Assess. Proj. Apprais. 2009, 27, 7-18. [CrossRef]

67. MOEF. Bangladesh Climate Change Strategy and and Action Plan; MOEF: Dhaka, Bangladesh, 2009.

68. General Economics Division. Sixth Five Year Plan FY2011-2015: Sectoral Strategies, Programmes and Policies; General Economics Division (GED): Dhaka, Bangladesh, 2011.

69. Ministry of Agriculture. National Agricultural Policy; Ministry of Agriculture: Dhaka, Bangladesh, 2013.

70. GoB. Coastal Zone Policy 2005. Available online: http://lib.pmo.gov.bd/legalms/pdf/Costal-Zone-Policy2005.pdf (accessed on 17 January 2016). 
71. GoB. National Livestock Development Policy; GoB: Dhaka, Bangladesh, 2007.

72. Government of Bangladesh. National Plan for Disaster Management 2010-2015; Government of Bangladesh: Dhaka, Bangladesh, 2010.

73. Mercer, J.; Kurvits, T.; Kelman, I.; Mavrogenis, S. Ecosystem-Based Adaptation for Food Security in the AIMS SIDS: Integrating External and Local Knowledge. Sustainability 2014, 6, 5566-5597. [CrossRef]

74. CCTF Approved Project of Bangladesh Climate Change Trust Fund. Updated on 9 December 2015. Available online: http: / /www.bcct.gov.bd/images/order/List.pdf (accessed on 20 December 2015).

75. Rashid, A.K. Asia Pacific Journal of Public The role of the bureaucracy in policymaking in Bangladesh. Asia Pac. J. Public Adm. 2014, 36, 150-161.

76. Gain, A.K.; Giupponi, C.; Renaud, F.G. Climate Change Adaptation and Vulnerability Assessment of Water Resources Systems in Developing Countries: A Generalized Framework and a Feasibility Study in Bangladesh. Water 2012, 4, 345-366. [CrossRef]

77. Renaud, F.G.; Sudmeier-rieux, K.; Estrella, M. The relevance of ecosystems for disaster risk reduction. In The role of ecosystems in disaster risk reduction; Renaud, F.G., Sudmeier-rieux, K., Estrella, M., Eds.; United Nations University Press: Tokyo, Japan, 2013.

78. Ayers, J.M.; Huq, S. Adaptation, development and the community. In Climate Adaptation Futures; Palutikof, J., Boulter, S.L., Ash, A.J., Smith, M.S., Parry, M., Waschka, M., Guitart, D., Eds.; John Wiley \& Sons: Oxford, UK, 2013; pp. 203-214.

79. Islam, A.; Shaw, R.; Mallick, F. Climate Change Adaptation Actions in Bangladesh. In Disaster Risk Reduction; Shaw, R., Ed.; Springer: Kyoto, Japan, 2013; pp. 143-163.

80. Banks, N.; Roy, M.; Hulme, D. Neglecting the urban poor in bangladesh: Research, policy and action in the context of climate change. Environ. Urban. 2011, 23, 487-502. [CrossRef]

81. Hills, T.; Pramova, E. Informing Decisions on Ecosystem-Based Approaches for the Adaptation of People in the Asia and Pacific Region; Center for International Forestry Research (CIFOR): Bogor, Indonesia, 2011.

82. Howgate, O.R.; Kenyon, W. Community cooperation with natural flood management: A case study in the Scottish Borders. Area 2009, 41, 329-340. [CrossRef]

83. Hossain, M.Z.; Sakai, T. Severity of Flood Embankments in Bangladesh and Its Remedial Approach. Agric. Eng. Int. CIGR J. 2008, X, 1-11. Available online: http://fpd-bd.com/wp-content/uploads/ 2015/09/Severity-of-Flood-Embankments-in-Bangladesh-and-Its-Remedial-Approach.pdf (accessed on 12 September 2016).

84. Chowdhury, M.R. The Impact of 'Greater Dhaka Flood Protection Project' (GDFPP) on Local Living Environment-The Attitude of the Floodplain Residents. Nat. Hazards 2003, 29, 309-324. [CrossRef]

85. Younus, M.A.F. Flood Vulnerability and Adaptation To Climate Change in Bangladesh: A Review. J. Environ. Assess. Policy Manag. 2014, 16, 1450024. [CrossRef]

86. Talukder, B.; Shamsuddin, D. Environmental Impacts of Flood Control Drainage and Irrigation (FCDI) Projects in a Non-Irrigated Area of Bangladesh: A Case Study. J. Transdiscipl. Environ. Stud. 2012, 11, 1-21.

87. Ayers, J. Resolving the adaptation paradox: Exploring the potential for deliberative adaptation policy-making in Bangladesh. Glob. Environ. Politics 2011, 11, 62-88. [CrossRef]

88. Tashmin, N. Policy Responses to Climate Finance in Bangladesh: An Anthropological Interpretation of Policy Making Process. Int. J. Res. Sociol. Anthropol. 2015, 1, 37-52.

89. Liu, J.; Ouyang, Z.; Miao, H. Environmental attitudes of stakeholders and their perceptions regarding protected area-community conflicts: A case study in China. J. Environ. Manag. 2010, 91, 2254-2262. [CrossRef] [PubMed]

90. Dewan, C.; Buisson, M.C.; Mukherji, A. The imposition of participation? The case of participatory water management in coastal Bangladesh. Water Altern. 2014, 7, 342-366.

91. Johnson, C.; Penning-Rowsell, E.; Parker, D. Natural and imposed injustices: The challenges in implementing "fair" flood risk management policy in England. Geogr. J. 2007, 173, 374-390. [CrossRef]

92. Burton, I.; Malone, E.L.; Huq, S. Adaptation Policy Frameworks for Climate Change: Developing Strategies, Policies and Measures; Lim, B., Spanger-siegfried, E., Eds.; Cambridge University Press: Cambridge, UK, 2004.

93. Huq, S.; Rahman, A.; Konate, M. Mainstreaming Adaptation to Climate Change in Least Developed Countries ( LDCS ). Clim. Policy 2003, 4, 25-43. [CrossRef] 
94. Tanner, T.; Lewis, D.; Wrathall, D.; Bronen, R.; Cradock-Henry, N.; Huq, S.; Lawless, C.; Nawrotzki, R.; Prasad, V.; Rahman, M.A.; et al. Livelihood resilience in the face of climate change. Nat. Clim. Chang. 2015, 5, 23-26. [CrossRef]

95. Ernstson, $\mathrm{H}$. The social production of ecosystem services: A framework for studying environmental justice and ecological complexity in urbanized landscapes. Landsc. Urban Plan. 2013, 109, 7-17. [CrossRef]

(c)

(C) 2017 by the authors. Licensee MDPI, Basel, Switzerland. This article is an open access article distributed under the terms and conditions of the Creative Commons Attribution (CC BY) license (http:/ / creativecommons.org/licenses/by/4.0/). 